\title{
Learning to remember and to forget: electrophysiological studies on attention-working memory interactions in typical development and ADHD
}

Citation for published version (APA):

Spronk, M. (2012). Learning to remember and to forget: electrophysiological studies on attention-working memory interactions in typical development and ADHD. [Doctoral Thesis, Maastricht University]. Maastricht University. https://doi.org/10.26481/dis.20120209ms

Document status and date:

Published: 01/01/2012

DOI:

$10.26481 /$ dis.20120209ms

Document Version:

Publisher's PDF, also known as Version of record

\section{Please check the document version of this publication:}

- A submitted manuscript is the version of the article upon submission and before peer-review. There can be important differences between the submitted version and the official published version of record. People interested in the research are advised to contact the author for the final version of the publication, or visit the DOI to the publisher's website.

- The final author version and the galley proof are versions of the publication after peer review.

- The final published version features the final layout of the paper including the volume, issue and page numbers.

Link to publication

\footnotetext{
General rights rights.

- You may freely distribute the URL identifying the publication in the public portal. please follow below link for the End User Agreement:

www.umlib.nl/taverne-license

Take down policy

If you believe that this document breaches copyright please contact us at:

repository@maastrichtuniversity.nl

providing details and we will investigate your claim.
}

Copyright and moral rights for the publications made accessible in the public portal are retained by the authors and/or other copyright owners and it is a condition of accessing publications that users recognise and abide by the legal requirements associated with these

- Users may download and print one copy of any publication from the public portal for the purpose of private study or research.

- You may not further distribute the material or use it for any profit-making activity or commercial gain

If the publication is distributed under the terms of Article 25fa of the Dutch Copyright Act, indicated by the "Taverne" license above, 
Summary 


\section{Summary}

Imagine making a complex assignment in a noisy classroom, or driving on a busy road while paying attention to traffic signs but ignoring advertisements. These environments (and numerous other environments in everyday life) require us to keep our goals active in mind and only pay attention to relevant information, while preventing irrelevant information from distracting us. To do this successfully, we need well-functioning cognitive control. Two important factors for cognitive control are working memory and attentional control. Working memory (WM) refers to our ability to temporarily maintain and manipulate a limited amount of information. Attentional control is the ability to select relevant information from the environment, while suppressing information that is irrelevant to our current task-goals. Both WM and attentional control have been found to be still immature in adolescents, which has been linked to the immaturity of networks consisting of frontal and parietal brain regions that are involved in both cognitive functions. Furthermore, impaired performance on WM and attentional control tasks is often found in adolescents and adults with attention-deficit hyperactivity disorder (ADHD). Since cognitive control has been associated with the successful development of other cognitive abilities like reasoning, problem solving, reading, mathematics, and fluid intelligence, it is important to closer examine the typical and atypical development of $\mathrm{WM}$ and attentional control.

Studies in healthy adults have already indicated that WM and attentional control are closely related functions, and depend on similar frontoparietal networks. By means of selective attention we determine which information enters WM for maintenance and manipulation (by selecting relevant and suppressing irrelevant information). The other way around, when available WM capacity is intentionally reduced, performance on tasks that require attentional control decreases. Since no research has been done on the developmental patterns of these interactions in adolescents yet, and considering that the development of both cognitive functions is of vital importance to the other cognitive abilities mentioned above, the aim of the present work was to examine the developmental course of interactions between WM and attentional control. Besides typical development, cognitive development in children and adolescents with ADHD was studied, since they are known to have problems related to attentional control and WM (Martinussen et al., 2005).

Chapter 1 introduces the rationale of this thesis, explains its main theoretical and methodological aspects and ends with the aims of this work and an outline of its chapters. With the present research we aimed to investigate a) the nature of the attention problems in young (5-7 year-old) children, by studying the underlying neural mechanisms of attentional control development in healthy children and children with attention problems (Chapter 2), b) the development of interactions between WM and attentional control in healthy adolescents, by examining the influence that intentionally reduced WM capacity has on interference control 
(Chapter 3), c) the developmental course of top-down modulation of selective attention on WM performance during adolescence, by manipulating the relevance of the to-be-remembered items in a WM task, thereby measuring attentional filtering efficiency (Chapter 4), and d) the development of WM and filtering efficiency in adolescents and adults with ADHD, who are known to have cognitive control deficits (Chapter 5). To address these issues, besides behavior, event-related potentials (ERPs: the electrophysiological responses of the brain to task-events) were measured, which have a very high temporal (millisecond) resolution, providing information on all stages of cognitive information processing in the brain.

Chapter 2 showed that young children (5-7 years old), who are not yet diagnosed with ADHD, but show early symptoms (as measured by questionnaires), performed worse than children without ADHD symptoms on an attention task which required them to respond to a target letter when a certain cue was given, but inhibit the response when this cue was absent. Behavioral data showed that children with ADHD symptoms especially experienced problems of attention, but not of inhibition. Moreover, ERPs also showed a deficit in the ability to allocate attentional resources to the task in a sustained manner in children with ADHD symptoms. In response to the cue, these children furthermore showed impaired orienting or a reduced ability to evoke attentional responses to the warning cue and, just before the target appeared, less visual attention for the upcoming stimulus. These findings suggest that attention problems are already present in young children with symptoms of ADHD, and might be better predictors than early hyperactivity/impulsivity symptoms (since the latter seem to be part of normal behavior at this age).

Together, the results of the studies in Chapter 3 and Chapter 4 indicate that in adolescents attentional control as well as WM are still immature, and develop into adulthood. In Chapter 3, adolescents and adults performed a dual-task that consisted of an attentional control (Stroop) task and a verbal WM (N-back) task. In the gender face-word Stroop task, poorer distracter suppression in the presence of a conflicting stimulus (e.g. the word "man" written on the face of a woman, see page 73) as measured by ERPs as well as worse behavioral performance was found in adolescents compared to adults, indicating still immature attentional control. Adolescents also performed worse on the verbal WM task, and (in Chapter 4) had lower digit span scores and worse behavioral performance in the change detection task. ERPs reflecting encoding and maintenance of items in memory (or the allocation of spatial attention) also showed prolonged development in this change detection study.

An important goal of the present thesis was to investigate the developmental course of the interactions between attentional control and WM during adolescence. In Chapter 3 this was examined by reducing WM capacity by manipulating load in the verbal WM task that was concurrently performed with the attentional control (Stroop) task. Although no effect of reduced WM capacity on behavior in the faceword Stroop task was found, refreshing of letter information during the Stroop task 
led to an increase in conflict detection-related ERP activity in adults. No such effect of reduced WM capacity was found in adolescents, but this might be explained by the already higher ERP activity without WM load, suggesting they experienced more conflict even without WM load. Letter refreshing also had an effect on the ERP activity related to response selection, but not to a greater extent for conflicting stimuli (e.g. the word "man" on a female face) than for non-conflicting stimuli (e.g. the word "man" on a male face).

In Chapter 4 a different approach was taken to examine WM and attentional control interactions. A change detection task with relevant items that had to be remembered and irrelevant items that had to be suppressed was used to examine the effects of attentional filtering efficiency on WM capacity (see page 100). The behavioral and ERP results from Chapter 4 suggested that adolescents were not able to suppress irrelevant information and were therefore not as efficient as adults in selecting only the relevant information for maintenance in WM. Furthermore, measures of filtering efficiency and WM capacity were correlated, indicating that lower WM capacity in adolescents is related to a reduced ability to block distracting items from being processed in WM. Immature frontoparietal networks are thought to be responsible for this developmental effect. In Chapter 3 and 4 adolescents between 12 and 16 years old were included in the adolescent groups. Future studies should take into account possible attentional growth spurts within this age range, and the role of WM in this, by including separate groups of young and old adolescents. Furthermore, functional MRI (magnetic resonance imaging) studies could identify which brain regions are involved in the $\mathrm{WM}$ and attentional control interactions observed in adolescents in future research.

In Chapter 5 the same change detection task was conducted in adolescents and adults with ADHD and age-matched controls. Results from this study again showed large developmental differences between adolescents and adults (with and without ADHD), but no deficits in filtering efficiency or WM capacity in ADHD patients. Only smaller CDA amplitudes (ERPs) with low load (maintenance of one item) were found in adolescents and adults with ADHD due to increases in ipsilateral activity, suggesting wandering of attention to the non-cued hemifield in these groups. The development of filtering efficiency and VSWM storage capacity in adolescents with ADHD was not different from that in typically developing peers when matched on IQ.

Finally, the results from the studies in this thesis were discussed and general conclusions were drawn in Chapter 6. Taken together, the studies on typical development showed that the interdependency of attentional control and WM is subject to developmental changes from adolescence to adulthood. On the one hand, interference control was shown to be differentially affected by changes in WM capacity in adolescents than adults. Lower availability of resources for top-down control was thought to be responsible for worse distracter suppression in adolescents. On the other hand, an inability to block distracter items from memory and a lower storage capacity resulted in worse performance on a visuospatial WM 
task in adolescents than adults. Possibly because of prolonged development of frontoparietal networks, responsible for both cognitive control functions, performance and ERP activity related to attentional control and WM was still immature in adolescents. Furthermore, the ADHD studies showed that young children with ADHD symptoms already have attentional problems, which might be good indicators for the risk of developing ADHD. Results from the last study showed similar patterns of WM and attentional control interactions in adolescents with and without ADHD when groups were matched on IQ, and provides no evidence for a developmental lag for WM-attention interactions in adolescents with ADHD. 
Samenvatting 


\section{Samenvatting}

Stel je voor dat je in een lawaaierige klas een moeilijke opdracht probeert te maken, of dat je op een drukke weg rijdt terwijl je probeert de verkeersborden in de gaten te houden, maar de reclameborden te negeren. Voor deze situaties (en voor ontelbare andere situaties uit het dagelijks leven) is het nodig om onze doelen actief in gedachten te houden en alleen op de relevante informatie uit de omgeving te letten, terwijl we proberen ons niet te laten afleiden door irrelevante informatie. Om dit succesvol te laten verlopen, hebben we goed functionerende cognitieve controle nodig. Twee belangrijke factoren voor cognitieve controle zijn werkgeheugen en aandachtscontrole. Werkgeheugen (WG) verwijst naar ons vermogen om tijdelijk een beperkte hoeveelheid informatie vast te houden en te manipuleren. Aandachtscontrole is ons vermogen om relevante informatie te selecteren, terwijl we informatie die irrelevant is met betrekking tot onze huidige doelen proberen te onderdrukken. Voor zowel WG als aandachtscontrole is gevonden dat deze nog niet volledig ontwikkeld zijn in de adolescentie, wat te maken heeft met de onvolwassenheid van netwerken bestaande uit frontale en pariëtale hersengebieden die betrokken zijn bij cognitieve controle functies. Ook in adolescenten en volwassenen met aandachtstekort hyperactiviteitstoornis (ADHD) wordt vaak een slechtere prestatie op WG- en aandachtscontroletaken gevonden. Aangezien cognitieve controle geassocieerd wordt met een goede ontwikkeling van andere cognitieve vermogens zoals redeneren, probleem oplossen, lezen, wiskunde, en fluïde intelligentie, is het belangrijk om de normale en atypische ontwikkeling van WG en aandachtscontrole beter te bestuderen.

Studies met gezonde volwassenen hebben al uitgewezen dat WG en aandachtscontrole sterk aan elkaar gerelateerd zijn, en afhankelijk zijn van dezelfde frontaal-pariëtale hersennetwerken. Door middel van selectieve aandacht kunnen we bepalen welke informatie in het WG wordt opgenomen om onthouden en gemanipuleerd te worden (door relevante informatie te selecteren en irrelevante informatie te onderdrukken). Andersom zien we dat, wanneer de hoeveelheid beschikbare WG capaciteit opzettelijk verminderd wordt, de prestatie op taken die aandachtscontrole vereisen afneemt. Omdat er nog geen onderzoek is gedaan naar de ontwikkelingspatronen van deze interacties bij adolescenten, en gezien het feit dat de ontwikkeling van beide cognitieve functies zo belangrijk is voor andere cognitieve vermogens zoals hierboven genoemd, was het doel van het huidige werk om het verloop van de ontwikkeling van interacties tussen WG en aandachtscontrole te onderzoeken. Naast de normale ontwikkeling is ook de cognitieve ontwikkeling van kinderen en adolescenten met ADHD onderzocht, omdat het bekend is dat zij problemen hebben die gerelateerd zijn aan aandachtscontrole en WG (Martinussen et al., 2005).

Hoofdstuk 1 begint met de beweegreden achter deze thesis, verklaart de belangrijkste theoretische en methodologische aspecten en eindigt met de doelen van 
dit werk en een overzicht van de verschillende hoofdstukken. Met het huidige onderzoek hebben we geprobeerd het volgende te bekijken: a) de aard van de aandachtsproblemen in jonge kinderen (5-7 jaar oud), door de onderliggende neurale mechanismen van aandachtscontrole-ontwikkeling te bestuderen in gezonde kinderen en kinderen met aandachtsproblemen (Hoofdstuk 2), b) de ontwikkeling van interacties tussen WG en aandachtscontrole in gezonde adolescenten, door de invloed van opzettelijk verminderde WG capaciteit op interferentiecontrole te bestuderen (Hoofdstuk 3), c) het ontwikkelingsverloop van top-down modulatie van selectieve aandacht op WG prestatie tijdens de adolescentie, door de relevantie van te onthouden items in een WG-taak te manipuleren, en zo de filter-efficiëntie van aandacht te meten (Hoofdstuk 4), en d) de ontwikkeling van WG en filter-efficiëntie in adolescenten en volwassenen met ADHD, waarvan bekend is dat ze een tekort aan cognitieve controle hebben (Hoofdstuk 5). Om het bovenstaande te onderzoeken, hebben we naast gedrag ook "event-related potentials" (ERPs; de psychophysiologische reacties van de hersenen op gebeurtenissen tijdens een taak) gemeten, welke een zeer hoge temporele resolutie hebben (van milliseconden), en zo informatie kunnen geven over alle fases van de cognitieve verwerking van informatie in de hersenen.

Hoofdstuk 2 liet zien dat jonge kinderen (van 5 tot 7 jaar oud) die nog geen diagnose ADHD hebben, maar vroege symptomen laten zien (gemeten door middel van vragenlijsten), een slechtere prestatie hadden dan kinderen zonder ADHD symptomen op een aandachtstaak waarbij ze op een bepaalde letter (stimulus) moesten reageren wanneer vooraf een speciaal teken werd gegeven, maar om deze respons te onderdrukken wanneer dit teken niet van tevoren aanwezig was geweest. De gedragsdata lieten zien dat kinderen met ADHD symptomen vooral problemen met de aandacht hadden, maar niet met het onderdrukken van de respons zelf. Verder lieten de ERPs van de kinderen met ADHD symptomen een tekort zien in het vermogen om de beschikbare aandacht doorlopend voor de taak te gebruiken. Als respons op het waarschuwingsteken lieten deze kinderen verder een verminderd oriënteren zien of een verminderd vermogen om een aandachtsrespons op te roepen wanneer dit waarschuwingsteken werd gegeven, en lieten ze vlak voor het verschijnen van de daaropvolgende stimulus minder visuele aandacht zien. Deze bevindingen wijzen erop dat aandachtsproblemen al op een jonge leeftijd aanwezig zijn in kinderen met symptomen van ADHD, en betere voorspellers zouden kunnen zijn dan vroege symptomen van hyperactiviteit/impulsiviteit (omdat deze laatste op deze leeftijd tot het normale gedragsrepertoire lijken te behoren).

Samen lieten de resultaten van de studies in Hoofdstuk 3 en 4 zien dat in adolescenten zowel aandachtscontrole als WG nog onvolwassen zijn, en zich nog verder ontwikkelen tot in de volwassenheid. In Hoofdstuk 3 namen adolescenten en volwassenen deel aan een duo-taak die bestond uit een aandachtscontrole-taak (Stroop taak) en een verbale WG-taak (N-back taak). In de gender gezicht-woord Stroop taak werd een slechtere distracter suppressie gevonden in adolescenten dan in volwassenen bij de aanwezigheid van een conflicterende stimulus (bijvoorbeeld 
het woord "man" geschreven op het gezicht van een vrouw, zie pagina 73) gemeten door middel van ERPs, en een slechtere prestatie in gedrag, wat wijst op een nog onrijpe aandachtscontrole. Adolescenten presteerden ook slechter op een verbale WG-taak, en hadden (in Hoofdstuk 4) een lagere cijfer spanne en een slechtere gedragsprestatie in een zogenaamde "change detection" taak (waarin men moest aangeven of één of meer items van kleur veranderd waren ten opzichte van eerder getoonde items op dezelfde plaats). ERPs die het encoderen en vasthouden van items in het geheugen reflecteerden (of het toekennen van spatiële aandacht daaraan), lieten een vóórtdurende ontwikkeling zien in deze change detection studie.

Een belangrijk doel van dit proefschrift was het ontwikkelingsverloop van de interacties tussen aandachtscontrole en WG tijdens de adolescentie te onderzoeken. In Hoofdstuk 3 werd dit onderzocht door de beschikbare WG-capaciteit te verminderen door de hoeveelheid informatie te manipuleren in de verbale WG-taak die tegelijkertijd met de aandachtscontrole (Stroop) taak werd uitgevoerd. Hoewel er geen effect van verminderde WG-capaciteit werd gevonden op het gedrag in de gezicht-woord Stroop taak, leidde het steeds opfrissen van letterinformatie tijdens de Stroop taak wel tot een toename in ERP activiteit gerelateerd aan conflict detectie (bv. bij het zien van het woord "man" op het gezicht van een vrouw) in volwassenen. Dit effect van verminderde WG-capaciteit werd niet gevonden in adolescenten, maar dit komt mogelijk doordat hun ERP activiteit al hoger was zonder de extra WG-lading, wat erop wijst dat ze al meer conflict beleefden zonder WG-lading. Het opfrissen van letterinformatie had ook een effect op de ERP activiteit die geassocieerd wordt met de selectie van een respons, maar niet méér voor conflicterende stimuli (bv. het woord "man" op het gezicht van een vrouw) dan voor stimuli zonder inwendig conflict (bv. het woord "man" op het gezicht van een man).

In Hoofdstuk 4 is een andere benadering gebruikt om interacties tussen WG en aandachtscontrole te onderzoeken. De change detection taak met relevante items die onthouden moesten worden en irrelevante items die onderdrukt moesten worden, werd gebruikt om de effecten van de efficiëntie van aandachstfilteren op WG-capaciteit te onderzoeken (zie pagina 100). De gedrags- en ERP-resultaten uit Hoofdstuk 4 wezen erop dat adolescenten niet in staat waren om irrelevante informatie te onderdrukken en daarom niet zo efficiënt waren als volwassenen in het selecteren van alleen de relevante informatie voor opslag in het WG. Verder waren de maten van filter-efficiëntie en WG-capaciteit ook gecorreleerd, wat er op wijst dat een lagere WG-capaciteit bij adolescenten gerelateerd is an een verminderd vermogen om afleidende items te blokkeren (met als gevolg dat deze items door adolescenten wel in het WG worden opgenomen). Mogelijk wordt dit ontwikkelingseffect veroorzaakt door nog onvolwassen frontaal-pariëtale netwerken. In Hoofdstuk 3 en 4 zijn adolescenten tussen de 12 en 16 jaar oud opgenomen in de adolescentengroepen. Toekomstige studies zouden rekening moeten houden met mogelijke groeispurten van aandachtsfuncties in deze leeftijdsperiode, en de rol van WG hierbij, door verschillende groepen bestaande uit jonge en oude adolescenten op te nemen. Verder zouden functionele MRI (magnetic resonance imaging) studies in 
toekomstig onderzoek kunnen identificeren welke breingebieden precies betrokken zijn bij WG- en aandachtsinteracties zoals gevonden in adolescenten.

In Hoofdstuk 5 werd dezelfde change detection taak afgenomen bij adolescenten en volwassenen met ADHD die in leeftijd gelijk waren aan de controlegroepen. De resultaten van deze studie laten wederom grote ontwikkelingseffecten zien tussen adolescenten en volwassenen (met en zonder ADHD), maar geen tekorten in filter-efficiëntie of WG-capaciteit in ADHD patiënten. Er werden alleen kleinere CDA amplitudes (ERPs) gevonden bij een lagere WGlading (het onthouden van één item) in adolescenten en volwassenen met ADHD doordat deze een toename in ipsilaterale activiteit lieten zien, mogelijk als gevolg van het afdwalen van de aandacht naar het niet-gecuede visuele veld in deze groepen. De ontwikkeling van filter-efficiëntie en visuospatiële WG-opslagcapaciteit in adolescenten met ADHD was echter niet verschillend van die in leeftijdsgenoten met een typische ontwikkeling, wanneer gematcht op IQ.

Tot slot werden de resultaten van de studies in deze thesis besproken en werden er algemene conclusies getrokken in Hoofdstuk 6. Samen lieten de studies over de normale ontwikkeling zien dat de onderlinge afhankelijkheid van aandachtscontrole en WG onderhevig is aan ontwikkeling in de periode van adolescentie tot volwassenheid. Aan de ene kant werd aangetoond dat interferentiecontrole op een andere manier beïnvloed werd door veranderingen in WG capaciteit in adolescenten dan in volwassenen. Een verminderde beschikbaarheid van bronnen voor top-down controle was verantwoordelijk voor de slechtere distracter suppressie die werd gevonden in adolescenten. Aan de andere kant werd een slechter vermogen om voor afleidende (irrelevante) items de toegang tot het geheugen te blokkeren en een lagere WG capaciteit in adolescenten verantwoordelijk gehouden voor de gevonden slechtere prestatie op een visuospatiële WG-taak in deze groep dan in volwassenen. Mogelijk waren gedrag en ERP activiteit die gerelateerd zijn aan aandachtscontrole en WG nog onvolwassen in adolescenten door een vóórtdurende ontwikkeling van frontaal-pariëtale netwerken, die verantwoordelijk zijn voor beide congitieve functies. Verder lieten de ADHDstudies zien dat jonge kinderen met ADHD symptomen al aandachtsproblemen hebben, welke goede indicatoren zouden kunnen zijn voor het risico om ADHD te ontwikkelen. De resultaten van de laatste studie in dit proefschrift lieten vergelijkbare patronen van WG-aandachtscontrole interacties zien in adolescenten met en zonder ADHD wanneer de groepen overeenkwamen in IQ, en levert geen bewijs voor het bestaan van een vertraagde ontwikkeling van WG-aandacht interacties in adolescenten met ADHD. 
